Jurnal Ilmiah Al-Syir'ah Vol. 18, No. 1 (2020): 28-49

Website: http://journal.iain-manado.ac.id/index.php/JIS

ISSN 2528-0368 (online) ISSN 1693-4202 (print)

\title{
THE STUDY OF SOCIAL JURIDIC AGAINST IMPLEMENTATION OF WAKAF IN MAKASSAR
}

\author{
Budiarti \\ Faculty of Sharia, Universitas Islam Negeri Alauddin Makassar, \\ J1. Sultan AlauddinNo. 63, Romangpolong, Somba Opu, Kec. Somba Opu, \\ Kabupaten Gowa, Sulawesi Selatan, Indonesia, 92113 \\ E-mail: budiartirahman@uin-alauddin.ac.d \\ Imelda Wahyuni \\ Postgraduate Program, Institut Agama Islam Kendari, \\ Jl. Sultan Qaimuddin No. 17, Baruga, Kec. Baruga,Kota Kendari, Sulawesi \\ Tenggara, Indonesia, 93116 \\ E-mail: imeldawahyuni80@yahoo.com
}

\begin{abstract}
Waqf is a legal act that lives, grows, and develops in the life of the Islamic community as one of the religious institutions that are considered capable of improving the welfare of the people. Along with this, the government has established organic legal products as a basis for optimizing the implementation of representation during community life through Law Number 41 of 2004 concerning Waqf. For this reason, this study analyzes the effectiveness of the application of legal products in improving the welfare of the people in Makassar City. The socio-juridical approach used during the research process. Observations, in-depth interviews, and document searches applied during data collection. The research confirms that the management of waqf has not run optimally as the basis for reference in legal products about waqf. The waqf not optimally because the socialization factor does not run optimally. Besides, the use of waqf objects that have not professionally managed leads to productive waqf. The factors that happen because it is a factor of understanding about waqf by Muslims. Waqf object factors, and factors of waqf management and professionalism of Nazir because it is very urgent to advocate the community and Nazir to optimally develop the potential waqf that has been represented by the community.
\end{abstract}

Keywords: Socio Yuridis, Waqf, People's Welfare

How to Cite: Budiarti, B., \& Wahyuni, I. (2020). The Study of Social Juridic Against Implementation of Wakaf in Makassar. Jurnal Ilmiah Al-Syir'ah, 18(1), 2849.

Permalink/DOI: http://dx.doi.org/10.30984/jis.v18i1.960

Copyright (C) 2020, Jurnal Ilmiah Al-Syir'ah 


\section{Jurnal Ilmiah Al-Syir'ah Vol. 18, No. 1 (2020): 28-49 \\ Website: http://journal.iain-manado.ac.id/index.php/JIS ISSN 2528-0368 (online) ISSN 1693-4202 (print)}

\section{INTRODUCTION}

Islamic law is a law based on Islamic religious beliefs. The basic principle of Islamic law is a legal tradition that is far from the secular paradigm to regulate human life in the world alone, but a legal pattern that is also oriented and believed to have an afterlife in this world. These elements strengthen the character of Islamic law, which cannot escape from theological aspects of religion.

Muslims in Indonesia are the largest and or majority in national and state life. The Pancasila state law guarantees freedom to practice religious teachings, including implementing Islamic law as an integral part of Islamic teachings. The country has a constitutional obligation to facilitate the framework to realize its existence as Rahmatan Lil 'Alamin.

Waqf, as a religious institution, is an implementation of the teachings of Islam that are trusted by Muslims as institutions that will improve the welfare of society. Therefore, the source of Islamic teachings, namely the Qur'an, has a healthy spirit, fights for human values, and upholds justice (Mantu, 2018).

The substance of Islamic law as a large order has a vast space to be used as a raw material in the process of establishing a legal system in the Pancasila state of law. Islamic law is wealthy with philosophical, sociological, and juridical content as a parameter in the making of judicial politics in the Republic of Indonesia. Among these are legal products regarding endowments contained in Act Number 41 of 2004 concerning Waqf and Government Regulation Number 42 of 2006 as amended by Government Regulation Number 25 of 2018 concerning the implementation of Law Number 1 of 2004 concerning Endowments.

Waqf is one of the religious institutions of Islam that known and practiced for a long time by Muslims, along with the entry of Islam in the archipelago. Waqf made a significant contribution to the development of Islam in Indonesia. Waqf is an Islamic legal institution that accepted in large parts of the archipelago. The overall conception of waqf becomes an integral part of the habits of Indonesian people that have existed for centuries (Hermawan, 2014).

Waqf is an Islamic institution that has a dimension of social welfare. The existence of waqf as a populist economic instrument has strategic value when compared to zakat. The difference, in principle, is in managerial aspects of empowerment. The zakat manager is obliged to distribute all zakat assets to groups entitled to receive zakat. In contrast, the waqf manager (nazhir) must maintain the sustainability of the waqf property so that it remains intact and used for the benefit of society at large.

Another aspect and strategic value of waqf in terms of its management are that waqf property can utilize at various levels of society without any social group restrictions. Is it from the ordinary people, the people from among the economically well-established, educated people, or unemployment? All of them can use waqf

Social Conflict Due To The Controversy Of Mosque's Qibla Direction In Sejiram Village, Sambas Regency 


\section{Jurnal Ilmiah Al-Syir'ah Vol. 18, No. 1 (2020): 28-49 \\ Website: http://journal.iain-manado.ac.id/index.php/JIS \\ ISSN 2528-0368 (online) ISSN 1693-4202 (print)}

property to build prosperity and build civilization. Besides, waqf property remains intact and can use continuously and the addition of assets forever. In the religious tradition is called amalyah charity (Mantu, 2018).

But in reality, that waqf in Indonesia, especially in Makassar, has not able to play a role in solving poverty, social and economic problems. Waqf is understandable because most of the existing endowments are not optimal in their management. Therefore, the enactment of the waqf law plays a significant role in increasing the economic resources of the community, because it expected that the waqf could manage professionally, to guarantee the socio-economic welfare of the people from various circles.

One of the fundamental obstacles in the management of waqf is Nazhir's very minimal ability and its management, which is still traditional, both concerning aspects of understanding waqf itself and aspects of competence to carry out functions as Nazir. Regarding issues of knowledge of the management of waqf, there are still some Nazirs who even understand that waqf is only in the form of objects which cannot move, especially land, and has not touched productive waqf.

Legislation relating to the representation expects to be able to realize the ideals of a prosperous and just society. The waqf instrument emphasizes the social responsibility of every individual who can share and work together to create goodness and prosperity. Welfare does not always have to mean an abundance of wealth and fulfillment of physical needs, but rather broadly, including the ability of the people to meet the needs of spiritual and intellectual development.

There is some literature related to this research; First, Agus Triyanta's research on "Problems of Endowment Management: Classic Concepts and the Limits of Innovation in Utilization in Indonesia" (Triyanta, A., \& Zakie, 2014). The study outlines the religious institutions of waqf so far in Indonesia only dominated by its use of social problems such as cemeteries, the establishment of schools, places of worship, and others; Second, Solikhul Hadi's research on "Economic Empowerment through Endowments" (Hadi, 2018). The study analyzes the potential sources of funds that can improve the welfare of the people through empowering waqf by maximizing partnerships from the institutions formed by the government and created by the community; Third, Salma Said's research on "Cash Waqf and Community Economic Empowerment" (Said \& Amiruddin, 2019). Said's research explores the potential for cash waqf to reduce poverty with various community empowerment programs with cash waqf so that it can be an alternative for capital investment intended for productive business actors.

Refer to the previous literature review, this research is different from earlier studies because previous researchers more studied the potential of alleviating poverty through the economic empowerment of the people with rich endowments. The development of productive waqf could do by maximizing the function of waqf partnership institutions, both those formed by the community and those created by the government. Besides, the development of rich endowments can increase 


\section{Jurnal Ilmiah Al-Syir'ah Vol. 18, No. 1 (2020): 28-49 \\ Website: http://journal.iain-manado.ac.id/index.php/JIS \\ ISSN 2528-0368 (online) ISSN 1693-4202 (print)}

through cash waqf programs as alternative investment financing. Meanwhile, in the study, the author does not only describe the urgency of productive waqf empowerment as one way to improve the welfare of Muslims. But want to explore whether the law on waqf has been running effectively or not. The application of the law on waqf has not carried out effectively; it will review any factors that become obstacles so that the form of the law about waqf does not run under the direction and ideals of the formation of law about waqf. Therefore, this paper can make a significant contribution to the authorities who are responsible for the application of the law on waqf is one of the religious institutions that are living, growing, and developing during society to improve the welfare of Muslims.

Based on observations on the implementation of waqf in Makassar City, the data held by the Makassar Ministry of Religion in 2018 still dominated usage for places of worship and education, such as mosques, mosques, madrasas, pesantren, orphanages, and cemeteries. While the use of utilization to increase public welfare in the economic field is still very minimal.

The Makassar Ministry of Religion in 2018 shows that the implementation of legal products regarding endowments in Makassar City has not been significantly useful in making various changes towards productive donations that can improve the welfare of Muslims. By increasing the management of waqf to productive waqf, is believed to be able to increase the power of the function of waqf as a religious institution that can run in harmony with the economic improvement in Makassar City.

Based on the description, the study of the effectiveness of the management of waqf as a religious institution that has integrated into the politics of state law based on Pancasila has significance to be studied in improving the welfare of Muslims so that its management carried out under the mandate of organic legal products concerning endowments.

\section{RESEARCH METHODS}

This research is a study of the application of waqf in improving the welfare of the people in Makassar City. The socio-juridical approach is used as an approach in analyzing research findings by referring to the provisions of the legislation relevant to endowments or by searching documents related to the focus of the problem under study. Furthermore, it connects with facts that occur in the field. During the research process, researchers collect data through observation, in-depth interviews, and document searches. The data obtained in this research activity identified and grouped according to the characteristics of the research objectives then analyzed qualitatively. Furthermore, the data that has collected and analyzed will be described as verbally (in language). The method adopted in analyzing the information finished through data reduction, which is choosing the main thing in accordance with the focus of the study.

Social Conflict Due To The Controversy Of Mosque's Qibla Direction In Sejiram Village, Sambas Regency 
Jurnal Ilmiah Al-Syir'ah Vol. 18, No. 1 (2020): 28-49

Website: http://journal.iain-manado.ac.id/index.php/JIS

ISSN 2528-0368 (online) ISSN 1693-4202 (print)

\section{RESULTS AND DISCUSSION}

\section{Description of the Condition Waqf Land Data in Makassar}

Based on data on the condition of waqf land in Makassar City, there are 493,961 M2 of waqf land located in 334 locations spread across 14 sub-districts, as can be seen in table 1 .

Tabel 1. Waqf land data in Makassar

\begin{tabular}{cccc}
\hline No. & Description & $\begin{array}{c}\text { Total } \\
\text { Location }\end{array}$ & $\begin{array}{c}\text { Total Area } \\
\text { M2 }\end{array}$ \\
\hline 1. & Data on land waqf & 334 & 493.961 \\
2. & The Waqf Land has AIW/APAIW & 207 & 410.807 \\
3. & Waqf land is not yet AIW & 29 & 27.168 \\
4. & Waqf land already certified & 85 & 55.806 \\
5. & Waqf land not yet certified & 249 & 438.155 \\
\hline
\end{tabular}

Source: Makassar City Ministry of Religion, tahun 2019

From table 1, the writer analyzes the status of waqf land spread over 14 districts in Makassar City. Does the existing waqf land have a Waqf Pledge Deed (AIW) or Substitute Pledge Deed Waqa Deed (APAIW) as proof of registration of waqf property at the Office of Religious Affairs (KUA) District. The table can exist seen that the waqf land in Makassar City that already has AIW / APAIW is 410,807 M2 in 207 locations and 27,168 M2 that has not AIW / APAIW in 29 areas.

Furthermore, it is necessary to know whether the waqf land that already has AIW already has a certificate or has been registered with the National Land Agency. This data confirms that the waqf land that has specialized is $55,806 \mathrm{M} 2$, located in 85 locations of the area of waqf land in Makassar City, which is 493,961 M2 situated in 334 locations. Thus the uncertified waqf land is 438,155 M2 in 249 locations.

The table illustrates that the number of uncertified waqf land is higher than that which is already certified. The number of uncertified waqf land is due to the lack of socialization from the local government, in this case, the Ministry of Religion and the National Defense Agency on the importance of waqf and also the lack of public understanding of the established waqf rules. In addition, it is also due to the still strong influence of customs in the community, that in giving one's assets a person is usually only entrusted to someone/board of trustees of a foundation or mosque without any written evidence of the agreement they made at the time of the endowment pledge.

From a juridical perspective, especially after the issuance of a law on the management of waqf, that the object of waqf in Makassar City is a very wide range of abuse or the mandate of people who donate their property. Such circumstances, 


\section{Jurnal Ilmiah Al-Syir'ah Vol. 18, No. 1 (2020): 28-49 \\ Website: http://journal.iain-manado.ac.id/index.php/JIS ISSN 2528-0368 (online) ISSN 1693-4202 (print)}

provide space someday the heirs can sue to the management of waqf about ownership of the waqf property. That's what happens a lot today. Therefore, it is a necessity for waqf managers, especially in waqf land objects to improve their legal status by taking care of the certification of waqf land with the competent authority to have legal force.

Regarding the description of the condition of waqf activity according to its use, it can be seen in table 2 .

Table 2. Data of Waqf Land by use in Makassar

\begin{tabular}{cccc}
\hline No. & Description & Total Location & Total Area M2 \\
\hline 1 & Mosque & 85 & 55.806 \\
2 & School & 249 & 438.155 \\
3 & Social and Others & 53 & 241.111 \\
4 & Grave & 17 & 171.424 \\
\hline
\end{tabular}

Source: Makassar City Ministry of Religion, tahun 2019

In table 2, it knows that there are 55,806 M2 of waqf land located in 85 locations of the waqf land used for the construction of mosques. There are 241,111 M2 of waqf land located in 53 areas of waqf land used for orphanages and graves.

Refer to table 2, it can assume that efforts to improve the welfare of the community through the management of waqf in Makassar City are very far from the expectations and mandate of licensed products as a proxy that has proven its productive power in improving the welfare of Muslims. The religious institutions of waqf have going on for a long time, the traditions of Islamic societies starting from the early era, and the development of Islam to the glory of the Islamic empire from time to time. Even in the form of a modern Islamic state such as the Republic of Indonesia.

So this paper reinforces Munir's (2013) argument that the management of waqf is a teaching that has been prescribed by Allah Almighty. As an institution in improving the welfare of Muslims has not been well managed. One of the contributing factors is Nazir's professionalism as the mandate bearer to continue the sustainability of the use of a property that has social value to fellow humans. The professionalism of a Nazir is an absolute necessity in the current era to manage waqf objects while still paying attention to the contents of the sacred text's values as the basis for the teachings about waqf itself.

\section{Effectiveness of the Application of Law No. 41 of 2004}

The effectiveness of the implementation of waqf law determined with the implementing apparatus, namely how the related device can carry out following the mandate of the law. The intended officers are the managers (nazhir) and then 


\section{Jurnal Ilmiah Al-Syir'ah Vol. 18, No. 1 (2020): 28-49 \\ Website: http://journal.iain-manado.ac.id/index.php/JIS ISSN 2528-0368 (online) ISSN 1693-4202 (print)}

community involvement in carrying out the legal rules so that the purpose and function of the waqf are following its designation, as explained in Article 22, that:

"Toward achieve the goals and functions of waqf, the waqf property can only designate for: (a) Means and religious activities; (b) educational and health facilities and activities; (c) assistance to the needy poor, neglected children, orphans, duties students, (d) progress and improvement of the economy of the people, and; e. other public welfare progress that is not contrary to sharia and legislation."

A good law is a law that is following the soul of the nation, so naturally, what destined broadly includes the application of waqf laws, which expected to be implemented effectively in societies, mainly Islamic societies.

Apart from that, the Head of the Makassar City Ministry of Religion explained that the existence of the waqf law had not effectively implemented, one of the reasons was because the community did not yet understand the importance of implementing the law regarding waqf management (Rosadi, 2019).

The indicators of whether the application of competent legal representation is related to this, can be seen whether the public understands, obeys, obeys, and implements and responds to the implementation of legal endowment products. Then it can be seen in table 3 .

Table 3. Effectiveness of the Implementation of Waqf Law

\begin{tabular}{cccc}
\hline No. & Answer Category & \multicolumn{2}{c}{ Respondent } \\
\cline { 3 - 4 } & & Frequency & Percentage \\
\hline 1 & Effective & 9 & $20 \%$ \\
2 & Not effective yet & 20 & $44 \%$ \\
3 & Less effective & 16 & $35 \%$ \\
\hline & Total & 45 & $100 \%$ \\
\hline
\end{tabular}

Source: Primary data, 2019

Based on data from table 3 , shows that among 45 informants, nine people or $(20 \%)$ stated that the effective implementation of waqf law, 20 people or $(44 \%)$ noted that the application of waqf law was not practical, and 16 people or $(35 \%)$ which states that the implementation of waqf law is not possible.

The data can see that the most dominant informant answered from questions related to the implementation of waqf law is not yet active. As for the indicators that it says that the effective implementation is that the rules are already perfect, the application of the law is maximal, and there is no dualism of authority that resolves 


\section{Jurnal Ilmiah Al-Syir'ah Vol. 18, No. 1 (2020): 28-49 \\ Website: http://journal.iain-manado.ac.id/index.php/JIS ISSN 2528-0368 (online) ISSN 1693-4202 (print)}

in the event of a waqf dispute, the public has maximally responded to the existence of the law.

The indicator of the ineffectiveness to implementation of the waqf law is that the material of the law is not yet perfect. The application of the waqf law is not optimal; there is the dualism of authority that resolves in the event of a waqf dispute, the public has not too responsive to the existence of the law. This means that the implementation of the Waqf Law is an indication that the community has not been well socialized, so the practice cannot be successful and efficient.

In addition, the ineffectiveness of the implementation of waqf is that there is still a lot of waqf land which until now there has not been a certificate of waqf land, this shows an indicator that before promulgation on representation and postpromulgation it turns out there are still many waqf lands that do not yet have a waqf certificate. This means that the effectiveness of the implementation of waqf law is one of which must be implemented comprehensively.

Furthermore, in Government Regulation No. 42/2006 concerning the Implementation of Law No. 41/2004 concerning Waqf in Article 39, it is reiterated that registration of a waqf land certificate is carried out based on the Deed of Waqf Pledge or Deed Substitute Deed Pledge Act. It means that each waqf land must include waqf land certificates carried out to strengthen ownership rights.

Indicators of ineffective implementation of waqf law are imperfect laws; the application of the law is less than optimal; the public is less responsive to the existence of the law on waqf (Mu'allim, 2017). The ineffectiveness of the implementation of waqf law could be due to the lack of public knowledge about the existence of waqf laws because the government did not do the socialization (Muntaqo, 2015).

The state of Indonesia is a state of law, a country that has regulations to regulate its citizens should be useful in a legal product, including waqf law. Hence, it needs to coupled with good legal education. The lack of knowledge that citizens have about the law tends to cause the citizens themselves to be unconscious in conducting a violation of law should the related parties continuously provide counseling about how the effectiveness of the implementation of the law, especially endowments to the public. 
Jurnal Ilmiah Al-Syir'ah Vol. 18, No. 1 (2020): 28-49

Website: http://journal.iain-manado.ac.id/index.php/JIS

ISSN 2528-0368 (online) ISSN 1693-4202 (print)

Therefore, the existence of every legal product by Indonesian citizens can be known as far as possible. These links can saw in table 4, namely:

Table 4. Public Knowledge of Law No. 41 of 2014 Concerning Endowments

\begin{tabular}{clcc}
\hline \multirow{2}{*}{ No. } & Answer Category & \multicolumn{2}{c}{ Respondent } \\
\cline { 3 - 4 } & & Frequency & Percentage \\
\hline 1 & Effective & 11 & $24,44 \%$ \\
2 & Not effective yet & 26 & $57,77 \%$ \\
3 & Less effective & 8 & $17,77, \%$ \\
\hline & & Total & $100 \%$
\end{tabular}

Source: Primary data, 2019

Based on the data in table 4, shows that among 45 informants, eleven people or $(24.44 \%)$ stated that they knew that public knowledge about the existence of Law No. 41 of 2004 concerning Waqf. Twenty-six people or (57.77\%) who said they did not understand that the public's knowledge of the existence of Law No. 41 of 2004 concerning Waqf, eigh people or $(17.77 \%)$ who stated they did not know that public knowledge about the existence of Law No. 41 of 2004 concerning Endowments.

This table provides information that most informants expressed public knowledge about the existence of Law No. 41 of 2004 concerning Waqf is still very minimal. Criteria do not know the most dominant answer. The indicator is that the public has never fully understood the existence of the law. This data means that several things can influence the understanding of the community related to the presence of the waqf law, for example, because they have never read, have read but have not understood it, or have never read it at all.

Apart from that, another influence is probably due to the waqf law that the government has never done an optimal outreach about the importance of the practice of waqf law or has already carried out, but the explanation is not complete, which results in the community not knowing it well. Lack of legal socialization program about waqf can affect a community's knowledge, especially in applying how the waqf legal system properly and correctly. Thus the public understanding of the existence of Law No. 41 of 2004 concerning endowments is one part of the waqf knowledge knowledge factors that can affect the effectiveness of the implementation of waqf laws in Indonesia.

According to (Hadi, 2018), that: "The existence of waqf law has not been effectively implemented, one of the things because the public does not yet understand the importance of the implementation of waqf law. That the waqf law is not effective in its application. It is necessary to socialize it to Nazir because many 


\section{Jurnal Ilmiah Al-Syir'ah Vol. 18, No. 1 (2020): 28-49 \\ Website: http://journal.iain-manado.ac.id/index.php/JIS \\ ISSN 2528-0368 (online) ISSN 1693-4202 (print)}

do not understand, so far, the use of waqf land has been hereditary, and it is difficult if the Nazir party has requested it ".

In line with that, (Triyanta, A., \& Zakie, 2014) said, that: "Knowledge of waqf law is still very lacking even today; there are still those who do not know of its existence, thus causing the implementation of waqf law not yet active. The point is that the waqf law has not been effectively implemented in the field and has not made the Nazis aware. Nazirs do not manage either waqf property until they do not take care of it and try to certify waqf property, one of the factors because it is due to the existence of waqf legal knowledge that is not understood".

Based on the information from various informants above. The author can confirm that the recruitment of executing apparatus and waqf managers (Nazir) should have adequate knowledge and education with good moral standards so that the entire process carried out can produce products that are beneficial and not detrimental public. all of this correlates if the public knows and understands the existence of the Waqf Law.

The implementation of waqf is very much determined by the executing apparatus, namely how the related device can carry out following the mandate of the law, the intended officers are the managers (nazhir) and then the community's involvement in enforcing the rule of law so that the purpose and function of the waqf is following its designation, as explained in

To achieve the goals and functions of waqf, the properties of waqf can only be designated for: a. Religious facilities and activities; $b$. educational and health facilities and activities; c. assistance to the poor, neglected children, orphans, scholarships, d. progress and improvement of the people's economy and other public welfare advancements that are not in conflict with sharia and statutory regulations.

The legislative, legal products regarding waqf as an adaptation of Islamic legal products politically, the law within the framework of the Pancasila legal state emphasized. That the potential sources of Islamic funding, such as waqf, need modern managerial management that is accountable and responsive to see opportunities in improving the welfare of the people as one of the instruments to alleviate poverty.

Therefore, it is necessary to take a strategic step for the institution of waqf, especially to the waqf managers (nazhir), to make a breakthrough to increase the usefulness of waqf such as making productive waqf movements, cash waqf, and investment waqf (Hadi, 2018).

Based on the results of this analysis, it revealed that empirically by referring to information by informants and observations, that the implementation of waqf law was not yet effective both systematically and simultaneously in its application. That a good rule is a law that is following the soul of the nation, then, of course, what

Social Conflict Due To The Controversy Of Mosque's Qibla Direction In Sejiram Village, Sambas Regency

Reza Akbar 
Jurnal Ilmiah Al-Syir'ah Vol. 18, No. 1 (2020): 28-49

Website: http://journal.iain-manado.ac.id/index.php/JIS

ISSN 2528-0368 (online) ISSN 1693-4202 (print)

meant broadly is including the form of legal products on patronage. Legal representation is a licensed product whose raw material taken from the tradition of Islamic law, which historically has suitability towards the people of the archipelago. Therefore, the spirit and soul of this legal material is one of the practices of Islamic teachings that have been tested sociologically during society.

\section{Management of Waqf in Improving People's Welfare}

Waqf is a religious institution that has high economic value; if it managed professionally, then its existence becomes something that can sustain the economy of the people. The function of waqf as required in Article 5 of Law No. 41 of 2004 concerning Waqf is to realize the potential and economic benefits of waqf property for the benefit of worship and to realize public welfare. Management of waqf in Makassar City after the enactment of the Waqf Law Number 41 of 2004 and Government Regulation Number 42 of 2004 has not demonstrated its professional management to improve the welfare of the people.

Management so far has only been to realize the function of waqf for the benefit of worship. The role of waqf can see from the informants' answers in table 5 :

Table 5. Informant's Response to the Function of Waqf

\begin{tabular}{clcc}
\hline \multirow{2}{*}{ No. } & \multicolumn{1}{c}{ Answer Category } & \multicolumn{2}{c}{ Respondent } \\
\cline { 3 - 4 } 1 & $\begin{array}{l}\text { The function of waqf for the benefit of } \\
\text { worship. }\end{array}$ & 20 & Prequency \\
\hline $\begin{array}{l}\text { The function of waqf is to advance public } \\
\text { welfare. }\end{array}$ & 16 & $35, \%$ \\
\hline $\begin{array}{l}\text { The function of waqf for the benefit of } \\
\text { worship, and at the same time, to promote } \\
\text { public welfare. }\end{array}$ & 9 & $20 \%$ \\
\hline \multicolumn{1}{c}{ Total } & 45 & $100 \%$ \\
\hline
\end{tabular}

Source: Primary data, 2019

Based on table 5, it can assume that the management of waqf objects in Makassar after the enactment of waqf laws and regulations has not run optimally. Because the understanding of the community, especially Nazir regarding the function of waqf property, is not appropriate, as stated in the juridical instruments about the representation. Therefore, it is necessary to pursue massive socialization to the entire community, especially Nazar, so that they know the function of waqf is not just for the sake of worship but, most importantly, is an effort to advance the economic welfare of the community. 


\section{Jurnal Ilmiah Al-Syir'ah Vol. 18, No. 1 (2020): 28-49 \\ Website: http://journal.iain-manado.ac.id/index.php/JIS \\ ISSN 2528-0368 (online) ISSN 1693-4202 (print)}

It was the urgency of the management of waqf for the orientation of the interests of advancing the welfare of the people, especially waqf property in religious institutions. The mosque is a religious institution that has the potential to be professionally managed to improve the health of the people, especially the mosque administrators. Besides, it allows for the development of a populist-based economy by opening productive waqf land in mosques, such as shophouses, mini markets, and others.

The waqf objects can be utilized through investments to run charitable and productive ventures. Managers (nadzir) need to get a creative idea in using waqf objects. We all hope that waqf objects such as unproductive land because it is not fertile should not just remain without the sustainable management of its beneficial aspects. Such conditions are a concern and therefore need to find alternative solutions so that the waqf object still functions following the waqf goals themselves (Aziz, 2017).

The Government of Indonesia has compiled a regulation on representation, which later became known as Law Number 41 of 2004. The later indicates that the Indonesian government paid serious attention to waqf institutions and signaled the government's seriousness to strengthen religious institutions, including waqf, as an effort to improve the welfare of the Ummah.

However, the law has not implemented optimally. Several factors influence the implementation of the law on representation, namely:

\section{The Factors of Understanding of Muslims about endowments}

A good understanding of the essence to realize the potential and economic benefits of property for the benefit of worship and to advance the welfare of the people is one of the factors causing factors that influence the implementation of waqf management in Makassar.

Awareness in carrying out the goals and functions of waqf is a view that lives in society about what is the essence of waqf, or a particular category in one's mental life that causes a person to be able to separate between true or untrue, good and bad.

The problem now is that people are not aware of how to use their property to be used as waqf property. Understanding of the goals, functions, and benefits of waqf is still shallow, including the low awareness of the community, especially with the effectiveness of implementing waqf implementation so that violations always found in the management of parishioners.

In line with that, (Said \& Amiruddin, 2019) said that:

"The people, especially South Sulawesi, are still not aware of how they use of their assets to use as waqf property; likewise the waqf managers or Nazhirs lack

Social Conflict Due To The Controversy Of Mosque's Qibla Direction In Sejiram Village, Sambas Regency 


\section{Jurnal Ilmiah Al-Syir'ah Vol. 18, No. 1 (2020): 28-49 \\ Website: http://journal.iain-manado.ac.id/index.php/JIS \\ ISSN 2528-0368 (online) ISSN 1693-4202 (print)}

understanding of the essence of utilization and how to develop the waqf object itself, whereas if it did then the act is very noble and can help the community generally prosperity"

Even though the juridical instruments regarding waqf made fulfill the philosophically and juridically determined requirements. The public awareness does not have a response to endow some of their assets to improve the welfare of the people, then the legal regulations that made will not be effective in people's lives.

The problem is the increasing number of people, the legal awareness related to the interests of waqf land (waqf property) in its utilization is also large and diverse and dynamic. Therefore, there may be a conflict of interest between humans, especially in carrying out the goals and functions of the waqf. Finally, the effort to use waqf as an effort to develop a prosperous economy of the people becomes problematic and does not improve.

It is a reality that most people's understanding of waqf is still conventional and traditional, that is, as is commonly done and understood during the society for generations. For example, speaking and used for the construction site of the mosque. This conventional waqf can only rely upon the physical construction of the mosque. As for fostering routine activities and other activities in the mosque, it cannot trust. Because usually, the endowments have started to stop speaking after the construction of the mosque is finished.

As a result, after some time the mosque was used, problems began to arise, funds needed to pay for water bills, electricity bills, mosque cleaning costs, teacher salaries and Friday preacher transport and routine recitation. These funds are regular or ongoing. On the other hand, there are no consistent sources of mosque funds. Finally, many mosques that are not well managed can only carry out limited activities.

For this reason, it is necessary to re-actualize the understanding of waqf; the consumptive agreement of waqf must change towards the knowledge of waqf, which is productive. Waqf objects that are only limited to land and particular objects must be developed more like the endowment of money.

\section{Endowment Object Status Factors}

The status of waqf objects in this study is one of the factors that influence the implementation of waqf to improve the welfare of the people. The state of waqf land can consider valid if it has fulfilled at least four pillars that are: The existence of a person who endows (waqf); there is property or something that is represented (mauquf); there is a place where the treasure is represented (mauquf alayhi); contract, which is the statement of the transfer of waqf property from those who endow it to those who given the waqf property to manage it (Nazhir). 


\section{Jurnal Ilmiah Al-Syir'ah Vol. 18, No. 1 (2020): 28-49 \\ Website: http://journal.iain-manado.ac.id/index.php/JIS ISSN 2528-0368 (online) ISSN 1693-4202 (print)}

Waqf object status has many problems because it caused the unclear condition of the land/endowment objects. Then there is no data collection on the state of the waqf object, nor is it recorded in the form of the Waqf Pledge Agreement (waqf certification) on the waqf object. It also influences that basically, the assets that have pledged to represent are the transfer of power and use of the proceeds for the public interest. At the same time, the status belongs to Allah SWT and not to the recipient of waqf.

The word "belonging to Allah" is a form of submission, or sincerity of the waqf. The type of surrender will become a new problem later on because many facts that occur due to unclear status of the endowment object, which causes the heirs to sue or deny many whatever done by his parents in the form of surrender or sincerity in donating his property.

The waqf essence is one form of transfer of rights to the object; therefore, the transfer of rights in paraphrase is different from the removal of the right to ordinary objects, because in the waqf has its advantages, which see as acts of worship in Islamic teachings. Expectations of transfer worship also expected to be safe in terms of the law.

Apart from that, the act of endowment in the transfer of objects expected to have no commercial value. But highlighted are the principles of social benefits so that grants become a religious institution that can be used as a means of life development, especially for Muslims to realize the welfare of the Ummah Muslims, both physically and mentally.

The utilizing waqf is not only for the benefit of mosques or places of worship but also for the needs of the community, such as for orphans, schools, making roads, markets, and other things as much as possible to provide benefits in people's lives and welfare. This form expects to make a valuable contribution to economic aspects and play a role in maintaining the balance of people's lives.

The reality in Makassar shows that there are still many cases of waqf disputes surfacing. This case proves that in the past, people donated their property for religious activities based solely on a real struggle to raise Islam without the need for written evidence, this is also because the representation in the literature may not have to write. Primarily before the issuance of Government Regulation Number 28 of 1977 concerning Ownership Representation, the ownership of the object was not wholly regulated in the form of positive law, and there was no confirmation that the endowment pledge must write in the way of endowment pledge.

Apart from that, before the issuance of Government Regulation No. 28/1977 concerning the Representation of Owned Objects, the change in the status of the endowed object can be carried out unilaterally by Nazir. This problem arises mainly because of the various forms of representation (family endowments, general endowments, and other endowments) and the absence of the obligation to register assets represented as legal entities.

Social Conflict Due To The Controversy Of Mosque's Qibla Direction In Sejiram Village, Sambas Regency 


\section{Jurnal Ilmiah Al-Syir'ah Vol. 18, No. 1 (2020): 28-49 \\ Website: http://journal.iain-manado.ac.id/index.php/JIS \\ ISSN 2528-0368 (online) ISSN 1693-4202 (print)}

This form shows that the status of waqf objects has not registered and even certified as waqf objects. Therefore, the condition of waqf objects can affect the management of waqf to improve the welfare of the Islamic community in Makassar.

According to Muhammad (Al-Nawawi, 1994): "That there are many unclear object status states. Then many Nazirs did not manage their Waqf property until they could not manage it and tried to certify it as Waqf property. The difficulty factor is getting clear data from the waqf who have died. Some of them become a problem of contact with the landowner. On the other hand, there is no strong evidence held by the waqif, only based on ordinary letters."

In connection with that, it must understand that the status of the waqf object must be clear and certain of the law. Because when the legal basis is not clear, then the waqf object will be easily distorted by certain parties, and inevitably influences efforts to realize community welfare. Thus, the legal certainty of the status of waqf objects must be clear and sure to avoid the possibility of heirs who sue or certain parties who want to take the properties of the waqf.

The thing that needs to complete is how to make available endowments property in various ways so that these objects do not fall into the hands of unauthorized parties, who may intend to seize or take by force against the existing endowment objects. Thus, to protect the waqf objects, what is urgently complete is to take security measures against the waqf objects as follows:

First, immediately give certificates of waqf property in all corners of the objects in the country. Besides, it familiar that so far, many waqf objects have fallen into the hands of unauthorized parties. This phenomenon must stop by giving certificates to objects that have a waqf status. The pattern of the implementation of waqf for a long time indeed more carried out using trust without providing elements of evidence. That can strengthen administrative (legal), therefore for waqf objects to save from its various formal problems; it legally protected through a waqf land certificate.

The granting of certificates of waqf objects does require the endurance of waqf Nazhirs, and the costs are not insignificant. So it involves the role of all parties concerned with the existence of waqf objects, especially the part of the National Land Agency (BPN) and local governments, to facilitate its management. The role of BPN is very significant in efforts to facilitate the process of making certificates for endowment land objects. Then the part of the Regional Government in each area of waqf land object about regional autonomy is also significant to participate in tackling the financing of certification, management, empowerment, and development of existing waqf objects. Therefore, there needs to be the publication of the importance of continual and intense certification of waqf objects so that the rest of the uncertified objects immediately get a definite legal position through the certificate of waqf land object. 


\section{Jurnal Ilmiah Al-Syir'ah Vol. 18, No. 1 (2020): 28-49 \\ Website: http://journal.iain-manado.ac.id/index.php/JIS \\ ISSN 2528-0368 (online) ISSN 1693-4202 (print)}

Second, provide full advocacy for waqf objects that are disputed or legally problematic. Advocacy support involves many parties, such as Nazhir waqf, the government, especially the ministry of religion, must be pro-active and care about the properties of waqf and the community at large. The provision of advocacy must complete in an integrated manner to get maximum results. This emphasis on cohesiveness is an essential thing. Because in resolving legal issues, especially concerning the topic of susceptible objects, closely related to a sense of material and formal justice that requires cohesiveness by all parties concerned, to achieve achievement in safeguarding objects endowments can be fulfilled.

Third, the implementation of Law Number 41 of 2004 concerning Endowments and Government Regulations. The application of waqf laws and regulations is essential for the protection of waqf objects in general because the maximum protection, utilization, and empowerment of waqf objects can complete.

Fourth, proactive use and empowerment of waqf objects. In addition to securing the legal sector, securing the designation and development fields must also be carried out, so that between legal protection and the nature of waqf objects which have a social purpose find its function

Some security measures for the waqf objects must be carried out immediately by all parties concerned. Apart from that, the strategy for securing waqf land can carry out in various ways, including safeguarding waqf land in terms of legal safekeeping of waqf land in terms of administration, ensuring waqf land in physical conditions, and securing waqf land in terms of supervision and guidance.

As already stated that the representation is the transfer of rights, both to movable objects and immovable objects, so that the dispute of waqf is very likely to occur between waqf or heirs and Nazir, and can also happen between Nazir and third parties.

\section{Management Factors and Nazhir Resources}

Management is one of the essential factors in the success of the management of an institution, both business institutions, educational institutions, and the state, including in waqf institutions. Waqf institution is an institution that becomes a guideline in Islam to regulate how the procedure of utilizing assets, which is commonly called waqf management.

The management of waqf is, of course, different from the control of other economic institutions such as infaq, and alms. Waqf has its distinction in implementing the principles and objectives of waqf. As mandated in waqf law products that the manager aspect (Nazir) must have the skills and competence in managing to create a managerial that is accountable, responsive, caring and transparency in managing waqf objects that have been safeguarded by the endowments. Finding a professional manager (Nazhir) certainly has its challenges

Social Conflict Due To The Controversy Of Mosque's Qibla Direction In Sejiram Village, Sambas Regency 
Jurnal Ilmiah Al-Syir'ah Vol. 18, No. 1 (2020): 28-49

Website: http://journal.iain-manado.ac.id/index.php/JIS

ISSN 2528-0368 (online) ISSN 1693-4202 (print)

in increasing the empowerment of the welfare of the people (Said \& Amiruddin, 2019).

Waqf management is the process of planning, organizing, directing, and supervising the efforts of the members of the organization and the use of other organizational resources to achieve the stated goals. The intended purpose is following the objectives of waqf, namely to realize the potential and economic benefits of waqf property for the benefit of worship and to advance public welfare

Management of waqf management occupies an essential position in the world of representation because what determines the most endowment objects is more useful or not useful, good or bad, good or bad, depending on the management of waqf (management pattern). Management of waqf management can affect the effectiveness of waqf management in improving the welfare of the people.

The indicators are a mature planning process, a systemic organizing process, a guiding process in useful guidance, an accountable oversight process, and maximum use of resources. The indicator can see in table 6 .

Table 6. Factors of Management of Waqf and HR Nazhir in Improving the Welfare of the People in Makassar.

\begin{tabular}{clccc}
\hline \multirow{2}{*}{ No. } & \multirow{2}{*}{ Answer Category } & \multicolumn{2}{c}{ Respondent } \\
\cline { 3 - 4 } & & Frequency & Percentage \\
\hline 1 & Influence & 30 & $67 \%$ \\
2 & Influence Less & 11 & $24 \%$ \\
3 & \multirow{2}{*}{ Not affect } & 4 & $9 \%$ \\
& \multicolumn{2}{r}{ Total } & $\mathbf{4 5}$ & $\mathbf{1 0 0 \%}$ \\
\hline
\end{tabular}

Source: Primary data, 2019

Based on the data in table 6 , shows that among 45 informants, 30 people or $(67 \%)$ who stated that the waqf management factor was very influential in improving the welfare of the people, 11 people or $(24, \%)$ who said that waqf management had less influence in improving welfare people, 4 people or $(9 \%)$ who stated that the waqf management factor did not affect the improvement of the people's welfare. That even if there is no endowment property manager, the deed is categorized as an ultimate endowment act.

Apart from that, waqf in its management must not sell, bequeathed, and granted. The administration is a condition that must apply to the assets represented. Prohibition of selling, passing down, and giving away waqf property is to prevent changes in the status of waqf property from public ownership to private property, so that waqf will remain forever a source of federal funds in general to improve its welfare. 


\section{Jurnal Ilmiah Al-Syir'ah Vol. 18, No. 1 (2020): 28-49 \\ Website: http://journal.iain-manado.ac.id/index.php/JIS \\ ISSN 2528-0368 (online) ISSN 1693-4202 (print)}

For this reason, not only must the management be carried out professionally, but the control of the waqf must also have a culture of transparency and accountability because it is a factor that must realize. The waqf rights over the assets of the waqf are feared that if lost, the existence of a culture of professional management, transparency and accountability, can be anticipated. given several waqif rights such as, the right to correct, clear and honest information about the condition of assets waqf; the right to be heard opinions and complaints related to the management of waqf used; the right to receive guidance and supervision regarding the management of waqf assets will more or less be fulfilled.

Management of waqf objects so far has managed "improvised" by using "trust management" and leadership centralism that override aspects of supervision, then in the management of waqf (waqf management) in a modern way it should highlight a more professional management system.

The principle of professional management should use as the spirit of the management of waqf objects in the context of taking broader and more tangible benefits for the benefit of the community at large (virtue). There are too many waqf assets managed by Nazhir that are not professional. So many waqf meanings do not function optimally. They do not provide benefits at all as expected; even many waqf assets are converted or sold to parties who are not responsible because Nazir who can not professionally manage endowments.

For this reason, Nazir professionalism wanted is reliable and has expertise in managing waqf objects correctly and adequately to improve the welfare of the people. Prophet Muhammad SAW. He has taught his people that everything, including problems related to waqf management, if complete, must meet at least the four minimum qualities possessed by the Prophet. It can categorize as a professional actor. It's just that in terms of modern management experience interpretation and widening of the more specific meaning.

In a modern management theory commonly referred to as TQM (Total Quality Management). However, if it traces within a complete theoretical framework, it can cone to these four things, namely trustful (trustworthy), Shiddiq (honest), fathanah (intelligent/brilliant), and tabligh (conveying pure/transparent information).

Apart from that, for the management of waqf to be more accountable by existing Nazir institutions to the government and the general public, efforts are needed to realize a condition as follows:

First, the movement to obtain transparency in all aspects of Nazir institutions, both internal and external. The existence of Nazar institutional transparency is a systemic jihad to cover up acts of dishonesty, corruption, manipulation, and so on. Transparency is an integral, important aspect in upholding the mandate of representation taught by Islamic values so that Islamic waqf institutions can use as benchmarks of openness in carrying out the moral

Social Conflict Due To The Controversy Of Mosque's Qibla Direction In Sejiram Village, Sambas Regency

Reza Akbar 


\section{Jurnal Ilmiah Al-Syir'ah Vol. 18, No. 1 (2020): 28-49 \\ Website: http://journal.iain-manado.ac.id/index.php/JIS ISSN 2528-0368 (online) ISSN 1693-4202 (print)}

responsibilities of Nazirs towards the order of living in a civilized society with justice and justice for the universe.

Second, Nazir institutions must obtain a system of public accountability, which encourages a climate of civil liability in the management of waqf property. The general responsibility is a form of implementing the nature of trust and honesty. Because trust and reliability must account for in the world and the hereafter, the endowment can use as a very promising vehicle for the benefit of credible public welfare. (very trusted) by continuing to uphold the value of professionalism with a good work ethic.

Third, Nazir institutions spearheaded an aspirational movement. People involved in Nazir institutions must encourage social systems that require the participation of many groups. The avoid unilateral decision-making patterns by the leadership elite within the board of trustworthiness, so that these efforts can reduce, even cover potentials that develop which could be far better or perfect. The principle of principle in the aspirational movement is a reflection of the nature of fairness in themselves or their environment (Prasetyo, 2017).

All actions, if carried out with good and right management, will undoubtedly produce sound output as well. Likewise, in the implementation of waqf, if it carries out with excellent and correct management, it will undoubtedly provide significant benefits for the interests of the community.

Management of waqf, which has so far been carried out by several parties that appear to be closed and unprofessional, should abandon, open management must apply with the principles of transparency and accountability and professionalism in its management.

The principle of transparency in modern management is a principle that must be implemented by a leader. If the principle of transparency and accountability abandoned, it will open up opportunities for deviations that deviate from the goals of the organization.

Therefore, leadership in the endowment institution of waqf management must be carried out by people who are professional and know the principles of modern management, planning (planning), organizing (organizing), mobilizing all potential (actuating), and supervision (control). With the principle of togetherness and help and advice advising in kindness will eliminate all acts of dishonesty, manipulation, and so on.

It is the management of waqf assets, many of which managed by Nazhir. Who are not professional, do not have adequate capabilities, so that waqf assets do not function optimally, do not even provide any benefits to the waqf targets as seen in table 7. 
Jurnal Ilmiah Al-Syir'ah Vol. 18, No. 1 (2020): 28-49

Website: http://journal.iain-manado.ac.id/index.php/JIS

ISSN 2528-0368 (online) ISSN 1693-4202 (print)

Table 7. Nazhir Manages Professional Waqf Objects in Improving the Welfare of the People

\begin{tabular}{cccc}
\hline \multirow{2}{*}{ No. } & Answer Category & \multicolumn{2}{c}{ Respondent } \\
\cline { 3 - 4 } & & Frequency & Percentage \\
\hline 1 & Agree & 4 & $9 \%$ \\
2 & Less Agree & 11 & $24 \%$ \\
3 & Disagree & 30 & $67 \%$ \\
\hline & Total & $\mathbf{4 5}$ & $\mathbf{1 0 0 \%}$ \\
\hline
\end{tabular}

Source: Primary data, 2019

Based on the data in table 7, shows that among 45 informants, 30 people or (67\%) stated that Nazhir did not professionally manage waqf objects in improving the welfare of the people. Eleven people or $(24 \%)$ who stated Nazhir were less professional at managing waqf in promoting the health of the people, 4 people or (9\%) who stated that Nazhir managed waqf objects professionally in improving the welfare of the people in Makassar.

Waqf management and Nazhir professionalism need to get attention in managing waqf objects. Optimally to increase productivity as an effort to realize the welfare of the people in Makassar through waqf must have principles for the protection of the people. Because if you look at the history and practice of waqf in the time of the Prophet Muhammad, it turns out that the existence of waqf bodies is very potential and decisive for the smooth running of the economy at that time.

Besides, the principle that must make hols in matters of this waqf is that the items represented are not exhausted or damaged. They must remain intact and become an eternal fund, and when someone has endowed something that can be represented, someone can no longer take back the goods that are represented. To protect these interests the state has regulated and facilitated the realization of a people-based economy.

\section{CONCLUSION}

From the results of this study, it can conclude that the effectiveness of the application of Law Number 41 of 2004 concerning Waqf in Makassar City has not been effective because it has not optimally socialized. Waqf has not yet use as one of the economic sources that can improve the welfare of the people. Another thing is the use of existing waqf has not been professionally managed mainly towards the empowerment of rich endowments. Several factors affect the implementation of the application of waqf to improve the welfare of the people in Makassar City, namely the understanding consideration of Islamic grants, endowment object factors, and endowment management factors and professionalism of Nazir. The research implicated that religious institutions have grown and developed for a long time in

Social Conflict Due To The Controversy Of Mosque's Qibla Direction In Sejiram Village, Sambas Regency 


\section{Jurnal Ilmiah Al-Syir'ah Vol. 18, No. 1 (2020): 28-49 \\ Website: http://journal.iain-manado.ac.id/index.php/JIS ISSN 2528-0368 (online) ISSN 1693-4202 (print)}

the lives of the community need to get the most attention to improve the welfare of the people. They are socializing the licensed products of the parish, increasing the understanding of the Islamic community's knowledge of the endowment itself, and advocating the managers (Nazir) endowments to improve professionalism with modern managerial endowments management towards enduring productive grants.

\section{ACKNOWLEDGMENT}

The authors thank the IAIN Manado Scientific Al-Syir'ah Journal Editor Team for helping to publish this article. Likewise, the authors would like to thank the Tompongpatu Education Foundation (YADITU), who assisted with this research.

\section{REFERENCES}

Al-Nawawi, Y. bin S. (1994). Shahih Muslim bi syarh an-Nawawi. Juz 10. Mu'assasah Qurthubah.

Hadi, S. (2018). Pemberdayaan Ekonomi Melalui Wakaf. Jurnal Zakat Dan Wakaf, 4(2), 229-244.

Hermawan, W. (2014). Politik hukum wakaf di Indonesia12(2), 147-161. Jurnal Pendidikan Agama Islam-Ta'lim, 12(2), 147-161.

Mantu, R. (2018). Islam dan Konstitusi: Analisis-Komparatifantara Teks Al-Quran dengan Pasal 29 UUD 1945. Jurnal Ilmiah Al-Syir'ah, 16(1).

Mu'allim, A. (2017). Ijtihad Ekonomi dalam Pengelolaan Aset Wakaf. $A L$ 'ADALAH, 14(2), 291-310.

Munir, Z. A. (2013). Revitalisasi Manajemen Wakaf Sebagai Penggerak Ekonomi Masyarakat. Journal de Jure, 5(2).

Muntaqo, F. (2015). Problematika dan Prospek Wakaf Produktif di Indonesia. AlAhkam, 1(25), 83-108.

Prasetyo, L. (2017). Kedudukan Hukum Pengambilalihan Tanah Wakaf Yang Batal Demi Hukum Untuk Dibagikan Sebagai Harta Warisan Dalam Kajian Undang-Undang No. 41 Tahun 2004 Tentang Wakaf. Jurnal Ius Constituendum, 2(1), 77-95.

Rosadi, A. (2019). Zakat dan Wakaf Konsepsi, Regulasi, dan Implementasi. Jakarta: Simbiosa Rekatama Media.

Said, S., \& Amiruddin, A. M. A. (2019). Wakaf Tunai dan Pemberdayaan Ekonomi 
Jurnal Ilmiah Al-Syir'ah Vol. 18, No. 1 (2020): 28-49

Website: http://journal.iain-manado.ac.id/index.php/JIS

ISSN 2528-0368 (online) ISSN 1693-4202 (print)

Masyarakat. Al-Mashrafiyah: Jurnal Ekonomi, Keuangan, Dan Perbankan

Syariah, 3(1), 43-55.

Triyanta, A., \& Zakie, M. (2014). Problematika Pengelolaan Tanah Wakaf: Konsep

Klasik dan Keterbatasan Inovasi Pemanfaatannya di Indonesia. Jurnal Hukum IUS QUIA IUSTUM, 21(4), 583-606. 